\title{
Economic Development Strategy of Halal Tourism in Sembalun Lombok Timur
}

\author{
Riri Lestari \\ Student at Master Program of Geography Education \\ Faculty of Social Science, Universitas Negeri Padang \\ Email: ririlestari093@gmail.com
}

\begin{abstract}
The purpose of this research is to create Economic Development Strategy in Halal Tourism Area in Sembalun of East Lombok Regency and formulate economic development strategy by doing analysis of AHP (Analythical Hierarchy Process). How to take informants in this study using Purposive Sampling. Based on the results of the analysis and discussion that has been done before, the strategy of Economic Development of Halal Tourism Area In Sembalun, East Lombok Regency is still in the low category seen from the income of society and life is still very simple. To overcome these problems then need some strategies that are growth strategy, development strategy and equity, and strategy with insight of space. The criteria for economic development are 1) capital assistance for society (0.863) 2) IT based technology (0.819) 3) Increasing employment opportunities for the community (0.781) 4) Higher education 0.716 5) Reducing Unemployment (0.673).
\end{abstract}

Keywords: Social Culture, Occupation-Revenue, Halal Tourism.

\section{Introduction}

Society is a complex for the study. Its existence has a very complicated dimension to explain, as well as having a broad component as the problem that must be reviewed with mulidimensi approach. Halal tourism is part of the tourism industry aimed at Muslim tourists. Tourist services in halal tourism refer to Islamic rules. tourism is a place used to conduct tourism activities. Tourist attractions can be natural attractions and buildings. Natural attractions can be beaches, mountains, and others, while tourist attractions can be buildings of historical relics, museums, and others. Tourism is a travel activity or part of which is done voluntarily and is temporary to enjoy the object and the tourist attraction (Law no.9 yr 1990 article 1).

In the Regulation of the Governor of West Nusa Tenggara Number 51 Year 2015 On Halal Tour Article 1, paragraph 6, Travel is a travel activity undertaken by a person or group of persons by visiting a certain place for recreation purposes, personal development, or studying the uniqueness of tourist attraction visited in term temporary time. Tourism is a wide range of tourism activities and supported by various facilities and services provided by the community, entrepreneurs, government, and local government. Tourism destination area hereinafter referred to as tourism destination is geographical area which is in one or more administrative area in which there are tourist attraction, public facility, tourism facility, accessibility, and also interconnected society and complete the realization of tourism.

His tourism attraction is not a stand alone component of tourism supply (tourism supply / tourism) The main component of tourism services or facilities is the accommodation sector or lodging For successful tourism activities in tourist destinations that have a natural attraction beforehand, the accommodation must provide quality in accordance with the demand of tourists who travel tourism to the destination tourism.Accommodation can be divided into commercial accommodation that includes: hotels, motels, boarding houses, bed and breakfast, cruisers, shelters, lodges, catering facilities and even farm based 
facilities, while non-commercial services from residence, mobile home, friend's house, etc. D besides this accommodation, it is also important to support this tourist attraction is food and beverage services, such as restaurants, restaurants, shops, health services and pharmacy, banks, theather, sports services and others etc. (Ansofino, Economica, Journal of Economic Education Studies Program STKIP PGRI West Sumatra Vol. 1 No. 1, October 2012)

Foreign tourists who are not satisfied will cause customer exit and in the long run to be something that is very potential to reduce the number of foreign tourists visiting tourist destinations. On the contrary, foreign tourists who are satisfied during and after a tour will create a positive image of tourism services and encourage the creation of loyalty for foreign tourists in the future, so that in the end will have a very significant contribution to the successful development of tourism sector such as the number of tourists, living, tourist spending, tourism product demand, image, and performance of the tourism industry (Basiya and Hasan: Tourism Dynamics Volume XI No. 2, October

It can be said that tourism policy seeks to provide a quality visitor experience and provide "profit" to destination stakeholders while ensuring that destinations are not compromised in environmental, social and cultural integrity. There are several functions of tourism policy, which are as follows: Defining the "rules of the game" which is the framework on which tourism operators are based. (Tourism and Hospitality Essentials (THE) Journal, Vol. I, No. 1, $2011-34$

1. Determine expected activities and behavior.

2. Provide a direction and guidance to all tourism stakeholders in a destination

3. Facilitate consensus based on specific strategies and objectives for a particular destination area.

4. Providing a framework for public / private discussion on the role and contribution of the tourism sector to the economy and to society in general.

5. Provide a framework for public / private discussion on the role and contribution of the tourism sector to the economy and to society in general.

6. Allow tourism to come face-to-face with other sectors of the economy.

In the field of population, the level of poverty in East Lombok experienced a significant decline from 2005 reached 295,381 people and fell in 2012 which reached 224,692 inhabitants. Labor Force Participation Rate in 2012 reached $60.56 \%$ with economic growth rate of $5.40 \%$. This proves our beloved region of East Lombok regency continues to develop with the percentage of poverty which only reaches $20 \%$ although this figure is quite high compared to the city of Mataram which reached $11.87 \%$. Although there are still many problems in the field of population experienced East Lombok districts such as high population density, infrastructure issues such as roads, and less attention to the government of remote communities.

The Targets of Tourism Development, According to Kusudianto (1996) in Doni and Hasan, the international and domestic targets of tourism development are: International targets of tourism development: a) Increasing foreign exchange earnings b) More economic development provides employment opportunities c) Income increase national, increased tax revenues, and expansion. d) Increased appreciation overseas about Indonesian culture e) Promotion of diplomatic relations with other countries. While targets in the country of tourism development: a) Creation of unity and unity of national identity of Indonesia b) Improvement of general welfare c) Presence of general attention to the environment d) Preservation of traditions and local customs e) Protection from private rights for a vacation. (Tourism Dynamics Volume XI No. 2, October 2012)

The economy of East Lombok Regency experienced a 6.12\% change in 1995, 8.17\% in 1996 and $5.52 \%$ in 1997 in line with the economic crisis in 1998. East Lombok economic growth tumbled to minus $(-2.81 \%)$ and within two years it began to appear. The livelihoods of the people of Lombok Timur are still dominated by the agricultural sector. In the future, an increase in population density will be followed by a 
shift in livelihoods from the agricultural sector to the industrial sector. The population density of East Lombok has increased from 370.92 inhabitants / Km2 (1995) and 598.16 persons / Km2 (2000).

The high tourism activity at the beginning of the year with various national scale MICE activities in Q1 / 2016 encouraged the growth of trade and services sector in NTB Province. The improvement in the performance of the non-mining economic growth is a positive indicator to alert the welfare of the people, especially through employment. "The effort needs to be intensified, thus creating a new source of inclusive and sustainable economic growth," The potential of flora fauna, social culture and soil fertility in the Sembalun area, inviting the attraction of outsiders to come and settle in this area. The Department of Tourism, companies and travel agents make this area as a tourist destination.

\section{Method}

This research is a step researchers by combining two forms of research that is qualitative and quantitative research. In the opinion of Sugiyono (2013: 23) states that the combination of research (Mixed Method) is a study that combines or combines the qualitative and quantitative methods to be used jointly in a research activity so that data obtained more comprehensive, valid, realiabel, and objective. But in this research more weighted on qualitative research and quantitative data as supporting qualitative research. Based on the source then the data used in this study can be distinguished on two types namely primary data and secondary data. Primary data obtained through direct measurement of the field and there are results of quantitative data calculations. While secondary data is data obtained from the literature, interviews, questionnaires and various institutions and electronic media that are qualitative. In this study also needed primary data. The techniques used in primary data collection are interview and observation techniques. This technique is expected to get accurate information in the readiness of educational institutions in support of halal tourism destinations in East Lombok regency. How to take informants in this research using Purposive Sampling. purposive sampling means the technique of intentional sempel. That is, the researchers determine their own samples taken not randomly, but determined by the researchers themselves.

\section{Result and Discussion}

The plains in East Lombok include mountains and lowlands that extend to the coastal areas, mountainous areas are in the northern region of Gunung Rinjani National Park with a peak height of 3726 meters above sea level. The middle to the South of the lowlands. District with the widest (terrain) area that is District of Sembelia, Sembalun and Jarowaru. These three subdistricts are quite laus because they are within the State forest area. While the District with the smallest area of sukamulia, sakra, and Montong Gading.

The administrative area of East Lombok is divided into 20 subdistricts from Jerowaru Subdistrict in the South to Sembelia sub-districts in the North Subdistricts There are 254 villages or kelurahan villages with details of 239 villages and 15 sub-districts. Aikmel Sub-district has the most number of villages or sub-districts of 24 villages, while the sub-district with the least number of villages or sub-districts is Sembalun Subdistrict which consists of only six villages.

Population is a very important development resource therefore the development of population condition is also an indicator that must be considered in designing development, where Sembalun Sub-district merupakn smallest population besides Sembelia and Sukamulia. Land use in Lombok Regency in East Lombok Regency is mostly used for agriculture business, total rice field area in 2016 covering 48,191 ha or about 30.02 percent from the total area of Regency. The rice fields are mostly planted with rice $(93.64 \%)$ either once, twice or three times in a year. 
Based on data that the authors obtained from East Lombok BPS geographically Sembalun region has an area of $217.08 \mathrm{Km} 2$ with a percentage of $13.52 \%$ with a distance from the Capital City to the Capital District is $49.0 \mathrm{Km}$. Many villages in Semabalun are 1 with a population of 2500 and 674 Households. While the area of land in Sembalun can be seen in the table below:

Table 1. Area of Rice Field and Type of Planting

\begin{tabular}{|c|c|c|c|c|c|}
\hline \multicolumn{6}{|c|}{ Land Area (Ha) } \\
\hline Rice Field & \multicolumn{2}{|c|}{ Land Is Not Rice } & Land Non Agricultural & \multicolumn{2}{|c|}{ Amount } \\
\hline 1155 & \multicolumn{2}{|c|}{16.620} & 3.933 & \multicolumn{2}{|c|}{21.708} \\
\hline \multicolumn{6}{|c|}{ Rice Field (Ha) } \\
\hline One time & Twice & Three times & Not planted rice & Rainfed & amount \\
\hline 906 & 5 & 0 & 191 & 53 & 1.155 \\
\hline
\end{tabular}

Source: Central Bureau of Statistics (BPS) of East Lombok

Based on the above table can be seen that the area of land used for the rice field is 1155 ha and not rice fields 16,620 ha while for planting there are 906 ha used for one planting in one year and 5 hectares for planting twice and the rest is not planted with rice about 191 ha. Based on the results of interviews conducted with the community after the rice harvest will be covered with various kinds of vegetables such as tomatoes, turnips, broccoli, and potatoes. With the problem of population and income of poverty problem also become heavy burden with the percentage of poor people around 18.46\% East Lombok is ranked second highest percentage of poor people, but if seen from total of poor population of East Lombok is the most in NTB around 216 thousand people live below the poverty line. Based on the strategy of economic development that must be developed in the mountain tourism area is done hierarchical analysis process or AHP (Analytical Hierarchy Process). Furthermore, the three criteria produce the alternative nine: 1) Reduce unemployment 2) increase prosperity 3) Higher education 4) Good natural management 5) IT based technology 6) Equity of development 7) Equity and population growth 8) Capital assistance 9) increase welfare work for the community. The consistency of the policy is 0.008 or is $<0.1$ so it can be continued by setting the starategi priority of economic development, based on interviews with community leaders, managers, youth tourism and visitors, the economic development strategy in Sembalun Lombok Timur region as the priority of economic development.

Based on the results of analysis and discussion in this research, five alternative economic development alternatives are offered; 1) IT capital support (0.863) 2) IT based technology (0.819) 3) Increasing employment opportunities for the community (0.781) 4) Higher education 0.716 5). Based on the picture above each development strategy can be realized if:

1. Capital assistance for the community

a. Assistance in the form of funds to promote agriculture and superior seeds

b. Help for tourism mounts sembalun

c. Help for the community and make various types of food by utilizing natural products such as potatoes, vegetables and others

2. IT-based technology

a. Complete agricultural equipment

b. Provide environmentally-based information and knowledge

c. The counseling conducted by the agricultural service

3. Increasing employment opportunities for the community

a. Opening new jobs around the shadows

b. Providing training for the community to create existing natural resources 
c. The existence of agricultural pesantren is a place where people can learn to better manage natural resources, develop more environmentally friendly farming and farming and entrepreneurship development in agriculture.

4. Higher Education

a. Opening school opportunities

b. For children who drop out of school in the program package A, B and C

c. Providing scholarships for underprivileged communities

5. Reduce unemployment

a. Provide socialization with entrepreneurs

b. Provide socialization about the potential of areas that must be developed

\section{Conclusion}

Based on the results of the analysis of the Economic Development Strategy Halal Tourism Area In Sembalun East Lombok is still in the low category of income from society and life is still very simple. To overcome these problems, then development strategy and equity, and strategy with insight of space. The criteria for economic development are (1) capital support for society (0.863) 2) IT based technology (0.819) 3) Increasing employment opportunities for society (0.781) 4) Higher education 0.716 5) Reducing Unemployment (0.673).

\section{References}

Ansofino. (2012). Potensi Daya Tarik Obyek Pariwisata Dalam Pembangunan Ekonomi Sumatera Barat Economica, Jurnal Program Studi Pendidikan Ekonomi Stkip Pgri Sumatera Barat Vol. 1 No. 1, Oktober 2012

Basiya R dan Hasan Abdul Rozak. (2012). Kualitas Daya tarik Wisata, Kepuasan Dan Niat Kunjungan Kembali Wisatawan Mancanegara Di Jawa Tengah. Dinamika Kepariwisataan Vol. XI No. 2, Oktober 2012

BPS. (2014). .Kabupaten Lombok Timur dalam Angka. Lombik Timur

Dony Wijaya dan Hasan Abdul Rozak. (2012). Optimalisasi Potensi Pengembangan Pariwisata Pabrik Bermuatan Pendidikan Di Pusat Produksi Madu Dan Benang Sutera Perum Perhutani Unit I Jawa Tengah Dinamika Kepariwisataan Vol. Xi No. 2, Oktober 2012

Marceilla Hidayat. (2011). Strategi Perencanaan Dan Pengembangan Objek Wisata (Studi Kasus Pantai Pangandaran Kabupaten Ciamis Jawa Barat), Tourism and Hospitality Essentials (THE) Journal, Vol. I, No. 1, $2011-33$

Pembangunan Nasional, Lembaran Negara Republik Indonesia Tahun 2006 Nomor 97

Peraturan Pemerintah Nomor 40 Tahun 2006 tentang Tata Cara Penyusunan Rencana

Sugyono. (2013). Metode Penelitian. Jakarta : Pearson Education, Inc.

Sutryo. (2010). Pengantar Ilmu Pariwisata. Bandung: Angkasa Offset.

Undang Undang Republik Indonesia No. 9 tahun 1990 pasal 1 ayat 3 